\title{
HTLV-1 modulates alternative splicing in CD4+ T cells in vivo
}

\author{
Morgan Thenoz ${ }^{1}$, Céline Vernin ${ }^{1}$, Christiane Pinatel ${ }^{2}$, Nicolas Nazaret ${ }^{3}$, Joel Lachuer $^{3}$, Didier Auboeuf ${ }^{4}$, Eric Wattel ${ }^{1}$, \\ Franck Mortreux ${ }^{1 *}$
}

From 15th International Conference on Human Retroviruses: HTLV and Related Viruses

Leuven and Gembloux, Belgium. 5-8 June 2011

Transcriptional dysregulation is the hallmark of HTLV-1 infected cells yet the impact of HTLV-1 on alternative splicing (AS) remains unknown. Given that about 95\% of genes are spliced, we investigated the exon expression profiling of CD4+ T-cell clones obtained by limiteddilution cloning of PBMC deriving from HTLV-1 carriers. Overall, 12 infected clones clustering in infected, uninfected, PHA-stimulated or unstimulated CD4+ T cells were compared for exon RNA content using Exon Chip Human microarray. The splicing index method was used to identify differentially expressed exons in paired comparisons. The exon content of 558 genes differed between infected and uninfected CD4+ T cells. Of these, only 76 genes were found differentially expressed at the whole transcriptional level. 360 exon events (185/ 558 genes) could be manually annotated in FASTDB database and corresponded to exon skipping (59 genes), mutually exclusive exons (151), 5' splice site (5'SS) (4), 3'SS (3), internal exon deletion (23), and intron retention (15). Some of these are already validated by exon specific RT-PCR experiments that are in progress. Exonbased hierarchical clustering analysis identified alternative exons associated with HTLV-1 infection and/or PHA stimulation. Ingenuity Pathway Analysis revealed new AS-based pathways of gene deregulation irrespective of whole transcriptional deregulation. These corresponded to hitherto unknown deregulation pattern of cell cycling and DNA damage response. Thus, HTLV-1 infection possesses a transcription-independent but ASbased signature that unmasks numerous new putative leukemogenic pathways.

\footnotetext{
* Correspondence: franck.mortreux@ens-lyon.fr

'Oncovirologie et Biotherapies, UMR5239 CNRS/ENS Lyon/UCBL/HCL, Hopital Pierre Benite, Lyon, France

Full list of author information is available at the end of the article
}

Author details

'Oncovirologie et Biotherapies, UMR5239 CNRS/ENS Lyon/UCBL/HCL, Hopital Pierre Benite, Lyon, France. ${ }^{2}$ Oncovirologie et Biothérapies, Centre Léon Bérard, Lyon, France. ${ }^{3}$ ProfileXpert, Neurobiotec Service, Bron, 69500, France. ${ }^{4}$ Institut National de Santé et de Recherche Médicale U590, Centre Léon Bérard, Lyon, France.

Published: 6 June 2011

doi:10.1186/1742-4690-8-S1-A168

Cite this article as: Thenoz et al:: HTLV-1 modulates alternative splicing in CD4+ T cells in vivo. Retrovirology 2011 8(Suppl 1):A168.

Submit your next manuscript to BioMed Central and take full advantage of:

- Convenient online submission

- Thorough peer review

- No space constraints or color figure charges

- Immediate publication on acceptance

- Inclusion in PubMed, CAS, Scopus and Google Scholar

- Research which is freely available for redistribution

Submit your manuscript at www.biomedcentral.com/submit
() Bïomed Central
C Biomed Central

C 2011 Thenoz et al; licensee BioMed Central Ltd. This is an open access article distributed under the terms of the Creative Commons Attribution License (http://creativecommons.org/licenses/by/2.0), which permits unrestricted use, distribution, and reproduction in any medium, provided the original work is properly cited. 